\title{
Mechanisims of asthma and allergic disease - 1083. CD23, Total lgE and Th1/Th2 cytokines in asthma patients
}

\author{
Anchoju Vijayendra Chary \\ From 2nd WAO International Scientific Conference (WISC 2012) \\ Hyderabad, India. 6-9 December 2012
}

\section{Background}

CD23 (FceRII), is a low affinity receptor for IgE, likely to influence IgE production and inflammation in allergic diseases. The aim of this study was to determine sCD23 and cytokine levels in asthma patients.

\section{Methods}

Soluble CD23, total histamine release, total IgE and Th1, Th2 cytokines were determined in blood samples of patients with asthma(50) and age and sex matched healthy volunteers (without signs of asthma) $(n=20)$.

\section{Results}

Serum sCD23 mean \pm SE was significantly increased $(\mathrm{p}<0.05)$ in asthma $(581.16 \pm 35.72 \mathrm{pg} / \mathrm{mL})$, when compared to controls $(429.49 \pm 31.29 \mathrm{pg} / \mathrm{mL})$. Similarly serum IgE mean \pm SE $(154.03 \pm 33.24)$ and blood histamine $(46.7 \pm 7.23)$ levels were increased significantly $(\mathrm{P}<0.01)$ in patients with asthma; while IFN $-\gamma$, a Th1 cytokine, was significantly lower $(\mathrm{P}<0.05)$ in asthma $(3.28 \pm 0.65)$ than in controls $(9.45 \pm 1.58)$. Pearson's correlation coefficient showed a significant $(\mathrm{P}<0.05$, $\mathrm{r}=0.50$ ) association between $\mathrm{SCD} 23$, IL-5 with serum IgE concentration, however, IFN- $\gamma$ was not correlated with IgE. Serum IL-4 and CD23 in buccal mucosa and stool samples were below detectable levels.

\section{Conclusions}

Our observations provide evidence on increased CD23 expression in asthma and a preferential activation of Th2 (IL-5) and suppression of Th1 (IFN- $\gamma$ ) response in

Microbiology and Immunology, National Institute of Nutrition (ICMR), Hyderabad, India adults with asthma. Positive correlation between IgE levels and sCD23 was detected in the asthma group.

Published: 23 April 2013
doi:10.1186/1939-4551-6-S1-P79

Cite this article as: Chary: Mechanisims of asthma and allergic disease 1083. CD23, Total IgE and Th1/Th2 cytokines in asthma patients. World Allergy Organization Journal 2013 6(Suppl 1):P79.
Submit your next manuscript to BioMed Central and take full advantage of:

- Convenient online submission

- Thorough peer review

- No space constraints or color figure charges

- Immediate publication on acceptance

- Inclusion in PubMed, CAS, Scopus and Google Scholar

- Research which is freely available for redistribution
() Biomed Central
C Biomed Central

(c) 2013 Chary; licensee BioMed Central Ltd. This is an Open Access article distributed under the terms of the Creative Commons Attribution License (http://creativecommons.org/licenses/by/2.0), which permits unrestricted use, distribution, and reproduction in any medium, provided the original work is properly cited. 